\title{
An Incomplete Arc: Analyzing the Potential for Violent Conflict in the Republic of Vanuatu
}

\author{
Abby McLeod and Michael Morgan
}

\section{I} ntroduction

This paper seeks to analyze the potential for violent conflict in the Republic of Vanuatu, a small island state in the South West Pacific. More specifically, it examines the likelihood of state level conflict and investigates local factors which might contribute to state destabilization. While conflict scholars have long engaged in the study of conflicts in the African and Balkan regions, engagements with Pacific conflicts have been comparatively recent. In particular, the Bougainville Crisis (1988-1997), the Indonesian suppression of West Papuan independence, post-referendum violence in East Timor (1999), the removal of democratically elected governments in Fiji and Solomon Islands (2000) and declining lawfulness in Papua New Guinea have ignited concerns over regional security. Indeed, the region to Australia's immediate north and northeast has gained global notoriety as an "arc of instability" or "arc of crisis," replete with "weak," "failing" and "failed" states. ${ }^{2}$

As members of the "arc," the countries of East Timor, West Papua, Papua New Guinea, Nauru, Solomon Islands, Vanuatu and Fiji are said to share a host of characteristics and experiences, ranging from lawlessness to civil warand including ethnic conflict, political instability, economic dysfunction and poor human development. In recent times, particular attention has been paid by academics, journalists and policy makers (specifically from Australia and New Zealand) to the Melanesian states of the arc (Papua New Guinea, Solomon Islands, Vanuatu and Fiji), stimulating critical debate about Australia's relations with the region, ${ }^{3}$ the development of a national conflict

1 Michael Maher, "Islands in the Storm," The Bulletin (20 June 2000), pp. 24-26.

2 See, for example, Ben Reilly, "The Africanisation of the South Pacific," Australian Joumal of International Affairs, vol. 54, no. 3 (2000), PP. 261-68; Aldo Borgu, Beyond Bali: ASPI's Strategic Assessment 2002 (Canberra: Australia Strategic Policy Institute, 2002); Sinclair Dinnen, Law and Onder in a Weak State: Crime and Politics in Paprua New Guinea (Honolulu: University of Hawaii Press, 2001).

3 Senate Standing Committee on Foreign Affairs, Defence and Trade. A Pacific Engaged: A ustralia's Relations with Papua New Guinea and the Island States of the South-West Pacific (Canberra: Senate Standing Committee on Foreign Affairs, Defence and Trade, 2003); Helen Hughes, "Aid has failed the Pacific," Issue Anabysis, no. 33, 7 May (Canberra: The Centre for Independent Studies, 2003); Susan Windybank and Mike Manning, "Papua New Guinea on the Brink," Issue Analysis, no. 30, 12 March (Canberra: The Centre for Independent Studies, 2003). 
policy ${ }^{4}$ and the growth of conflict studies at Australian universities (e.g., Centre for Conflict and Post-Conflict Studies, Asia Pacific, ANU; Centre for Peace and Conflict Studies, University of Queensland).

The Republic of Vanuatu, while beleaguered by resurgent political instability, poses the most obvious challenge to the collective identity of the so-called "arc" states. While the 1980 "Santo Rebellion" or "Coconut War" attracted international attention, neither the rebellion nor subsequent riots, such as the Ifira Land Riot (1988) and the VNPF riot (1998), have been significant; only three lives were lost as a consequence of these events, one of which was accidental. ${ }^{6}$ Many ni-Vanuatu attribute the limited magnitude of contemporary conflicts to the ongoing importance of "traditional" modes of dispute resolution, particularly chiefly intervention. However, pessimistic observers of developments in the "arc" place Vanuatu on a shared trajectory with Solomon Islands, Fiji and Papua New Guinea, with limited regard for country-specific circumstances. ${ }^{7}$

This paper seeks to provide an analysis of the potential for violent conflict in Vanuatu, a unique socio-cultural environment within the broader Melanesian region. While recognizing the limitations of early warning systems, the analysis draws upon the early warning literature, which employs a variety of quantitative and qualitative techniques to assess potential risks and analyze conflicts. In recent years, a number of key agencies-both national and international-have developed checklists of conflict indicators. Examples include the Forum on Early Warning and Early Response's (FEWER) A Manual for Early Warning and Early Response, the World Bank's Conflict Analysis Framework and the European Commission's Check-list for Root Causes of Conflict. ${ }^{10}$ Despite variations in approach, each of these checklists promotes the examination of political, economic and social contexts as a means of ascertaining the likelihood of violent conflict.

In examining these contexts in Vanuatu, we suggest that despite the presence of certain factors thought to be conducive to violent conflict, niVanuatu do not face imminent violent conflict. Moreover, we note that while

\footnotetext{
4 AusAID. Peace, Conflict and Development Policy. Canberra: AusAID, 2002.

5 Richard Shears, The Coconut War: The Crisis on Espiritu Santo (North Ryde, NSW: Cassell Australia, 1980).

6 Abby McLeod, "Women, peace and security: An examination of the role of women in the prevention and resolution of conflict in Vanuatu," 2004, Unpublished consultancy report prepared for UNIFEM, Suva, Fiji.

7 Maher, "Islands in the Storm"; Reilly, "The Africanisation of the South Pacific"; Borgu, Bgyond Bali.

8 Forum on Early Warning and Early Response (FEWER), A Manual for Early Warning and Early Response. [Online, cited 5 April 2006]. Available from http://www.acdi-cida.gc.ca/cida_ind.nsf/ d86cbc87319a898c8525677e0072d6f8/90b568f55073d47185256aef00657be8/\$FILE/Co7.pdf.

9 World Bank, Conflict Analysis Framework. [Online, cited 3 April 2006]. Available from http:// siteresources.worldbank.org/INTCPR/214574-1112883508044/20657757/CAFApril2005.pdf.

10 European Commission, EU Checklist for not causes of conflict. [Online, cited 3 April 2006]. Available from http://europa.eu.int/comm/external_relations/cpcm/cp/list.htm.
} 
the identification of "root causes" allows for the recognition of potential "flashpoints," the triggers of violent conflict and the will to address conflict issues often remain opaque until the outbreak of hostilities. Consequently, the paper interrogates not only the likelihood of violent conflict in Vanuatu, but also the usefulness of early warning systems.

The paper comprises four sections. First, we examine the definition of conflict to establish a working framework for discussion. Second, we examine the regional setting. Third, we undertake a systematic analysis of "conflict indicators" in Vanuatu and fourth, we make projections and provide suggestions for the prevention of conflict in Vanuatu.

\section{Defining Conflict}

Conflict studies incorporates diverse academic and professional fields; scholars engaged in the prediction, analysis and resolution of conflict, practitioners occupied with the management, transformation and resolution of conflicts, international organizations concerned with the prevention of conflict, governments and non-government organizations. Despite the abundance of engagements with conflict, there is little consensus on the "root causes" of conflict and key terms, such as "peace-building"-and even "conflict" itself-remain ill defined." While in its simplest sense, the term "conflict" may be used to refer to disagreements between individuals or groups, it is primarily the latter of these with which conflict scholars are concerned, focusing upon behaviour that may be destructive of persons, properties and systems, as opposed to disputes, which are typically negotiable. ${ }^{12}$

Quantifiable indicators, such as number of casualties, number of persons displaced and military expenditure, delineate further the types of conflict with which conflict scholars engage. However, the inconsistent application of these indicators renders the term "conflict" interchangeable with terms such as "armed conflict," "war" and "civil war." For example, Project Ploughshares defines "armed conflict" as "a political conflict in which armed combat involves the armed forces of at least one state (or one or more armed factions seeking to gain control of all or part of the state), and in which at least 1,000 people have been killed by the fighting during the course of the conflict." ${ }^{13}$ However, the Uppsala Conflict Data Project defines armed conflict as "a contested incompatibility that concerns government or territory or

11 Alan Tidwell, "Questions on Conflict Analysis and Peacebuilding," State, Society and Governance in Melanesia Project Discussion Paper, 2003/2 (Canberra: Research School of Pacific and Asian Studies, 2003), pp. 1-6.

12 John Burton, Conflict: Resolution and Prevention (New York: St Martin's Press, 1990), p. 2.

13 Project Ploughshares, Armed conflicts report 2005. [Online, cited 3 April 2006]. Available from http://www.ploughshares.ca/libraries/ACRText/Summary2004.pdf. 
both where the use of armed force between two parties results in at least 25 battle-related deaths. Of these two parties, at least one is the government of a state. ${ }^{\text {14 }}$ According to Collier, an internal conflict with at least 1,000 battlerelated deaths constitutes a "civil war," 15 a definition-albeit with greater qualifications- that is similarly employed by the Correlates of War Project. ${ }^{16}$

The pliable use of the term conflict renders the development of appropriate policy and response (the concern of both conflict scholars and practitioners) difficult, with the task of developing conflict prevention strategies being particularly challenging. This challenge is even more acute when engaging with conflicts in third world contexts, where local and foreign understandings of conflict potentially differ greatly. In the Vanuatu context, for example, discussions and focus groups held with bureaucrats and grassroots people revealed that to ni-Vanuatu, the word "conflict" connotes a broad range of behaviours including interpersonal disputes, inter- and intra-group disputes, armed fighting and violent crime. ${ }^{17}$

Given that conflict prevention strategies in such locales rely heavily upon local ownership, there is a clear need for the co-operative development of locally meaningful definitions of conflict with which external assistance actors can engage. This is indeed a challenging, but necessary task, as definitions of conflict will inevitably vary not only between countries, but also within. For example, what is deemed a conflict in a rural area will at times differ greatly from urban conflicts. While both academics and local people (primarily educated elites) question regional generalizations about the inevitability of conflict, the security of the Melanesian states has become an increasingly regional endeavour, with the deployment of regional peacekeeping forces in Bougainville and Solomon Islands, and the Pacific Islands Forum development of declarations on conflict and security matters, such as the Honiara Declaration (1992), the Aitutaki Declaration (1997) and the more recent Biketawa (2000) and Nasonini (2002) declarations. ${ }^{18}$

14 Mikael Eriksson, Peter Wallensteen and Margareta Sollenberg, "Armed conflict, 1989-2002," Joumal of Peace Research, vol. 40, no. 5 (2003), p 597.

15 Paul Collier, "Economic causes of civil conflict and their implications for policy." [Online, cited April 5 2006]. Available from http://72.14.203.104/search?q=cache:IOOuxPujAVY]:www. worldbank.org/research/conflict/papers/civilconflict.pdf+collier+economictcauses+of+civil+ conflict+and+their+implications+for+policy\&hl=en\&gl=au\&ct=clnk\&ecd=2, p. 5.

16 Correlates of War Project Homepage. [Online, cited 3 April 2006]. Available from http:// www.umich.edu/ cowproj/.

17 McLeod, "Women, peace and security," p. 8.

18 Michael Morgan, "Converging on the arc of instability? The fall of Barak Sope and the spectre of a coup in Vanuatu," in Ron May, ed., "An of Instability'? Melanesia in the Early 2000s (Canberra and Christchurch: The State, Society and Governance in Melanesia Project (ANU) and the Macmillan Brown Centre for Pacific Studies, 2003), pp. 41-54; Abby McLeod, "Report on the National Security Worksop, Vanuatu, 2004." [Online, cited 6 April 2006]. Available from http://rspas.anu.edu.au/ papers/melanesia/conference_papers/0403_vanuatu_report.pdf. 


\section{The Regional Setting}

The immediate region in which Vanuatu is situated is the cultural area known as Melanesia, which includes the countries of Papua New Guinea, Solomon Islands, Fiji and Vanuatu, the French overseas territory, New Caledonia, and the Indonesian province, Irian Jaya (West Papua).

The largest conflicts in the region (in terms of both casualties and number of actors involved) have been the 1988-1997 Bougainville Crisis, ${ }^{19}$ the ongoing conflict in Irian Jaya, ${ }^{20}$ the Solomon Islands crisis of 1998- 2004 ${ }^{21}$ and the Fiji coups of 1997 and $2000 .{ }^{22}$ By the standards of the Correlates of War Project, only the Bougainville Crisis (for which reported conflict related deaths range from 8,000 to 20,000$)^{23}$ constitutes a genuine armed conflict or civil war; less than 250 people died as a result of the Solomon Islands Crisis and approximately 32 deaths occurred during the Fiji coup in $2000 .{ }^{24}$

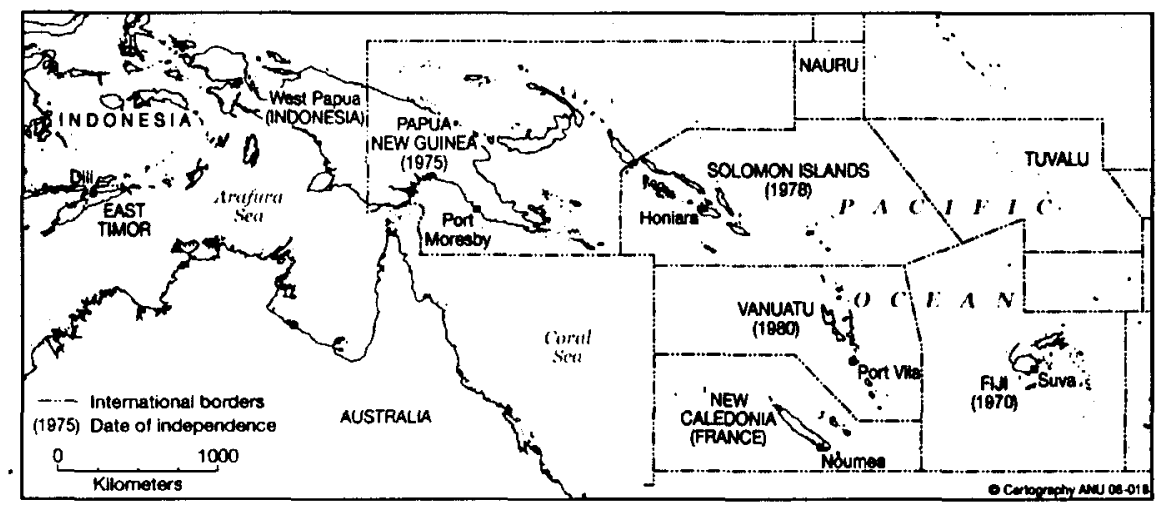

Map 1: The Melanesian States (with dates of independence and capital cities)

19 Sinclair Dinnen, Ron May and AnthonyJ. Regan, eds., Challenging the State: The Sandline Affair in Paprea New Guinea (Canberra: National Centre for Development Studies and the Department of Political and Social Change, Research School of Pacific and Asian Studies, ANU, 1997); Matthew Spriggs and Donald Denoon, eds., The Bougainville crisis: 1991 Update (Canberra: Research School of Pacific Studies, ANU, in association with Crawford House Press, 1992).

20 Robin Osborne, Indonesia's Secret War: The Guerrilla Struggle in Irian Jaya (Sydney: Allen \& Unwin, 1985); TAPOL, "Hotspots of Violence and Brutality Emerging in West Papua," AWPA Newsletter, vol. 21 (26 October 2000).

21 Sinclair Dinnen, "Winners and Losers: Politics and disorder in the Solomon Islands 2000 2002," Journal of Pacific History, vol. 37, no. 3 (2002), pp. 285 - 298.

22 Brij Lal and Michael Pretes, eds., Coup: Reflections on the Political Crisis in Fiji (Canberra: Pandanus Books, 2001).

23 See, for example, The Courier Mail, Brisbane, Australia, 11 May 1998, p. 9; Sean Dorney, The Sandline Affair - politics, mencenaries and the Bougainville Crisis (Sydney: ABC Books, 1998), p. 37; UNIFEM, WomenWarPeace.org Homepage. [Online, cited 3 April 2006]. Available from http:// www.womenwarpeace.org.

24 UNIFEM, WomenWarPeace.org Homepage. 
The Melanesian states are central to the "arc of instability," being characterized as unstable and, hence, potential security risks to their citizens and regional neighbours. Despite the great diversity of Melanesia-the most linguistically diverse region in the world-these countries are unified by a number of shared characteristics, which supposedly render them prone to conflict. These characteristics include sub-standard economic performance; tensions between "traditional" and introduced governance structures; a lack of clear land policy; ethnic tensions; socio-economic disparities; poor governance; declining traditional values, and a detachment between state and society. ${ }^{25}$ Few scholars have sought to dislodge the underlying assumption that conflict is somehow inevitable.

\section{Predicting Violent Conflict in Vanuatu}

The Republic of Vanuatu comprises an archipelago of some $\mathbf{8 0}$ islands, approximately 68 of which are inhabited. Formerly known as the New Hebrides, until 1980 the republic was administered jointly by France and Britain under the Anglo-French Condominium, an arrangement that left a legacy of bifurcated education, legal and administrative systems. ${ }^{26}$ At independence, the Republic of Vanuatu declared three official languages; French, English and Bislama.

The official population of Vanuatu was 186, 678 in 1999, 43 percent of which was under the age of 15 . The ratio of males to females is $106: 100$ and the population is expanding at the rate of 2.6 percent per annum. Urban population growth is particularly rapid (4.2 percent), with 21.5 percent of the nation's population now residing in Port Vila and Luganville. The majority of people (78.5 percent) continue to reside in the rural areas of Torba, Sanma, Penama, Malampa, Shefa and Tafea provinces. ${ }^{27}$

25 Ben Reilly, "The Africanisation of the South Pacific"; Ray Anere, Ron Crocombe, Rex Horoi, Elise Huffer, Morgan Tuimaleali'ifano, Howard Van Trease \& Nikenike Vurobaravu, "Security in Melanesia, Fiji, Papua New Guinea, Solomon Islands and Vanuatu," Pacific Islands Forum Secretariat, Forum Regional Security Committee Meeting, 25-26 June 2001, Suva, pgs. 4, 7-9; A. Retiere and H. Schurmann-Zeggel, "Conflict Prevention and Peace Consolidation in the South Pacific, Papua New Guinea, Solomon Islands, Fiji Islands." European Commission and UNOPS [Online, cited 6 April 2006]. Available from http://www.antenna.nl/ecsiep/conflict/docu/sp02.pdf, p. 43; S. Siegmund, "Insecurity and Conflicts in the Pacific Region." Analysis and Conclusions from the Seminar on Security and Conflict Prevention in the Pacific Region held in Brussels on 30th June 2003. Pacific Issues Paper no. 7 (Brussels: Pacific Unit, European Commission, 2003), p. 5.

26 See Howard Van Trease, Melanesian politics: Stael blong Vanuatu (Christchurch: Macmillan Brown Centre for Pacific Studies, University of Canterbury; Fiji, Suva: Institute of Pacific Studies, University of the South Pacific, 1995).

27 National Statistics Office, Vanuatu. The 1999 Vanuatu National Population and Housing Census. Port Vila: National Statistics Office, 2000. 
Until the late-1980s external forces were understood to be the major threat to Vanuatu's stability. ${ }^{28}$ Vanuatu's own troubled independence experienceat which time large sections of the country, supported by elements of the French administration and American libertarians, attempted to secedehas been cited as an indicator of potential instability. ${ }^{29}$ During this period, political differences between the British and French colonial administrations overlapped with religious conflict between Catholic and Protestant missions. The more significant conflicts, however, were played out between political supporters of the nationalist Vanua'aku Pati government (admittedly, a government dominated by Anglophone Protestants) and a raft of interests, Christian denominations and language groups involved in the Santo Rebellion. The Santo Rebellion was suppressed with assistance from Australia and Papua New Guinea in a matter of days. ${ }^{30}$ However, the contested sea border between Vanuatu and New Caledonia compounded Vanuatu's support for the Kanak independence movement and revived concerns that the French would intervene in Vanuatu's domestic politics. ${ }^{31}$

By the mid-1980s, Australian academics and policy makers collapsed the Cold War fear of Soviet expansion into the Pacific with their fear of a radicalized Vanuatu. In the decade after independence, Australian policy makers perceived in the growth of relations between Vanuatu and Libya and the Soviet Union serious threats to Vanuatu's sovereignty and, more importantly, to ANZUS policy imperatives in the South West Pacific. ${ }^{32}$ Such concerns subsided with the ending of the Cold War.

More recently, the threat posed by international crime syndicates utilizing Vanuatu's tax-free haven status and strict banking secrecy have been highlighted as potential sources of instability. At the Forum Security Committee meeting in Port Vila 2000, former Prime Minister Barak Sope noted that "the concern over external threats has been replaced by the concern over ... drug trafficking and money laundering. ${ }^{n 3}$ In 1996, a US State Department report on the danger of money laundering in Vanuatu rated the penetration of Vanuatu's tax haven by drug traffickers as medium

28 See A. Albinski, "The Security Perspective" in F. Mediansky, ed., Strategic Co-peration and Competition in the Pacific Islands (Sydney: Centre for South Pacific Studies, University of New South Wales, 1995), pp. 186-37; Anere et al., "Security in Melanesia"; Matthew Gubb, Vanuatu's 1980 Santo Rebellion: International Responses to a Microstate Security Crisis, Canberra Papers on Strategy and Defence, 107 (Canberra: Australian National University, 1994).

29 Anere et al., "Security in Melanesia."

30 John Beasant, The Santo Rebellion: an Imperial Reckoning (Honolulu: Heinemann/University of Hawaii, 1984).

31 Gubb, Vanuatu's 1980 Santo Rebellion.

32 Albinski, "The Security Perspective," p. 128.

33 Barak Sope, Opening Statement by the Vanuatu Prime Minister, Forum Regional Security Committee Meeting. [Online, cited April 4 2006]. Available from http://www.sidsnet.org/francais/ pacific/forumsec/news/2000/jul06.htm. 
to low. ${ }^{34}$ These issues percolated until September 11, 2001, when terrorist attacks on the World Trade Center in New York brought the potential threat of terrorists to the fore in the Western world. Further pressure was therefore brought to bear on Vanuatu to cease being a potential conduit point and haven for terrorists' and drug traffickers' money.

The evidence suggesting that Vanuatu is a major money-laundering centre, with the attendant problem of this status, is currently circumstantial or anecdotal. Money laundering remains a concern because of Vanuatu's strict bank secrecy, its lack of foreign exchange controls and the ease of creating offshore shell corporations. The OECD and European Union have pressured Vanuatu to relinquish its offshore financial status, established by the AngloFrench Condominium in 1970, but this has been resisted by the current administration. While the potential for illegal activities being harboured by Vanuatu's bank secrecy provisions is real, there is little evidence of this having impacted either on grassroots ni-Vanuatu or, at this stage, of having destabilized the state. Despite the precedent set in the Caribbean, Vanuatu has experienced neither an influx of weaponry and nor is there clear evidence of the establishment of foreign criminal cartels, both of which represent transparent destabilizing elements.

In recent years, the relative emphasis of threat perception has shifted from external factors to domestic ones. While external security threats are undoubtedly real, Vanuatu's inclusion in the "arc of instability" has been predicated largely on domestic factors, namely, the longstanding instability of the Police Force (VPF), including its paramilitary wing, the Vanuatu Mobile Force (VMF). In 1996, disgruntled VMF officers claimed 980,000 USD in outstanding allowances and abducted the president to highlight their cause. Also in 1996, an MP for Malakula and a former commandant of the VMF was charged with seditious conspiracy stemming from allegations that he plotted the downfall of the Vohor government. ${ }^{35}$ The case against him collapsed on the grounds of lack of evidence and the officer who implicated the MP received a suspended sentence of two years. In 2002, bilateral donors paid out the monies owing to the VMF. However, the periodic refusal of ministers to agree that payments should be made at all, the lack of funds in state coffers to acquit such payments, the lack of records covering what per diems were owed and the lodgement of claims by several officers who were not entitled to allowances delayed the reconciliation of these issues.

\footnotetext{
34 US Department of State, International Narcotics Comtrol Strategy Report March 1996: Financial Crimes and Mong Laundering. [Online, cited 28 March 2006]. Available from http://www.hri.org/ docs/USSD-INCSR/95/Financial/Chapter11.html.

35 See David Ambrose, "A Coup that Failed? Recent Political Events in Vanuatu, "State, Society and Governance in Melanesia Project Discussion Paper, 1996/03, (Canberra: Research School of Pacific and Asian Studies, 2003).
} 
In 2002, police acting under direction from a troika of senior officers arrested the fifteen members of the Police Services Commission (PSC) on charges of "seditious conspiracy" arising from irregularities in the appointment of Commissioner of Police, Mael Apisai, selected to purge antigovernment elements from within the police and VMF. Shortly afterwards, a group of VMF officers arrested Apisai and the Police Services Commission including the attorney general, the secretary to the president and the ombudsman. While most VMF officers supported Apisai, members of the VPF opposed his appointment. The Supreme Court overturned Apisai's appointment and directed the Police Services Commission to settle on an acting commissioner in preparation for the appointment of a commissioner. However, the decision was oriented towards diffusing tension between the government and the dissident officers: the Police Service Commission's guidelines for selecting the police commissioner are vague, the apparent political interference in the selection process notwithstanding. When the government launched a procedural counterstrike fears of civil strife were raised again. The officers who initiated Apisai's arrest were charged with mutiny and incitement to mutiny. When VMF officers loyal to the government went to arrest the three officers, a tense standoff ensued, which was only ended through the intercession of the National Council of Chiefs (Malvatumauri) and non-government organization representatives. While there are fears that factionalism between the VPF and the VMF might lead to organized violence, until 2002 there had been no major breakdown in relations between the VPF and the VMF, and even the 2002 incident was remedied relatively quickly.

While participation in the resolution of conflict is not a constitutionally defined role of the National Council of Chiefs, in notable instances, such as the tensions between the VPF and VMF, they have played a pivotal-and publicly sanctioned-role in brokering peace. The role and nature of contemporary chieftainship is frequently debated in contemporary Vanuatu, with both locally based leaders and members of the elected National Council of Chiefs simultaneously claiming authority as traditional leaders. ${ }^{36}$ The National Council of Chiefs is a constitutional body comprising representatives of traditional leaders elected from each province. It has a "general competence to discuss all matters relating to custom and tradition and may make recommendations for the preservation and promotion of ni-Vanuatu culture and languages." ${ }^{37}$ However, Parliament is only officially required to consult council members in relation to questions of land tenure..$^{38}$

36 See, for example, Lamont Lindstrom, "Chiefs in Vanuatu today," in Geoffrey White and Lamont Lindstrom, eds., Chiefs Today: Traditional Pacific Leadership and the Postcolonial State (Stanford: Stanford University Press, 1997), pp. 211-28.

37 Constitution of the Republic of Vanuatu, Chapter 5, Article 30.

38 Constitution of the Republic of Vanuatu, Chapter 12, Article 76. 
The centrality of chiefs, both local and national, is frequently cited as an explanation for the relative absence of conflict and lawlessness in Vanuatu. At the local-particularly rural-level, state penetration is extremely limited, resulting in the virtual absence of formal law and justice mechanisms, such as police and national courts. In these settings, while the state institutions of Island Courts function, it is primarily chiefs who guide community order through "informal" dispute resolution procedures (e.g., mediation), although their power is sometimes contested (albeit quietly), particularly by those who are marginalized by traditional notions of right and wrong, such as women and youth. At the national level, the role and function of chiefs has been widely discussed in relation to the prescription of their powers via legislation. Despite such debate, however, local and national chiefs in Vanuatu symbolize continuity with an idealized past and continue to play a vital role in the maintenance of social order.

\section{Political instability and violent conflict}

Alongside the aforementioned security concerns, political instability in Vanuatu is widely perceived as a potential source of violent conflict. Elsewhere in Melanesia, political instability was a factor in the breakdown of social order-notably contributing to bloody ethnic conflict in Solomon Islands ${ }^{39}$ and African precedents similarly suggest that under such conditions organized violence becomes the primary route to wealth, power and political survival. ${ }^{40}$ However, despite the chronic lack of coherent policy, corruption, the politicization of the bureaucracy and poor governance (induced by parliamentary instability), Vanuatu has remained peaceful. While the rivalry between politicians in Vanuatu has threatened to escalate, for example, through the mobilization of the disciplined forces or political supporters to augment claims to power, since 1980 there has been no entrenched violent conflict between political groups.

Political instability is symptomatic of Vanuatu politics, in which the primary concern is the marshalling of parliamentary numbers rather than the interrogation of policy performance-the duty of parliament-or the provision of coherent policy - the duty of government. National politicians in Vanuatu often assume a pragmatic approach to allegiance and appear motivated primarily by staying in power. Especially in times of political upheaval, defections to other parties and the formation of new parties are common, an environment that has prevailed since the late 1980s, when the major political parties fragmented. This was most obvious between 1995 and

39 Tarcissius Tara Kabutaulaka, "Beyond Ethnicity: The Political Economy of the Guadalcanal Crisis in the Solomon Islands," State, Society and Governance in Melanesia Project Working Paper, 2001/01, (Canberra: Research School of Pacific and Asian Studies, 2001), pp. 1-3.

40 See, for example, Phillippe Le Billon, Untitled, The Conflict, Security and Development Group Bulletin, May-June (2001), pp. 2 - 3. 
1997, when the government changed three times via votes of no confidence and there were eight major coalition changes. ${ }^{11}$

Although the motives of individual politicians are often emphasized, political allegiance is also decided at the constituency level. Local community leaders (such as chiefs and pastors) play a crucial role in the initial selection and endorsement of candidates and continue to exert influence throughout the incumbency of a member. Dissatisfaction with the performance of political parties or the fear that politicians are subverting a community's interests to opportunistic ends have recently been highlighted by community leaders as reasons for defection, protest or revolt, potentially in the form of violent conflict. ${ }^{42}$

Endemic regime instability in Vanuatu has undermined durable policy formation and implementation since the 1990 s, especially macro-economic policy. ${ }^{43}$ During this period, the downturn in the economy and allegations of government mismanagement and corruption inspired a shift towards deregulation and public sector reform under the Comprehensive Reform Program (CRP), a program of reforms designed to promote equity and social development which commenced in 1998 with the support of multilateral and bilateral donors and key domestic stakeholders. Whether or not reforms enacted under the CRP have encouraged political stability is debatable, although the ADB has begun an institutional strengthening project in the national parliament. In the absence of a political party that commands a simple parliamentary majority, the potential for a return to the political flux and policy stasis of the 1990s remains serious, particularly in the event that key politicians create instability opportunistically for personal gain or political survival. The link between political instability and the potential for violent conflict however, remains tenuous.

\section{Economic stability and violent conflict}

While economic instability is frequently associated with violent conflict, vertical wealth distribution within a given country is not a predictor of serious violent conflict or civil war. A brief survey of countries in which internal conflict has arisen in the last fifty years indicates that middle income countries such as Iraq and Bosnia have experienced civil conflict, as have the poorest countries in the world (Somalia, Uganda). In some areas conflict followed periods of economic growth; in others, it emerged from economic

41 Michael Morgan, "Political Chronicles: Vanuatu 1995-1998," Joumal of Pacific History, vol. 33, no. 3 (1998), pp. 287-93.

42 Michael Morgan, "Converging on the arc of instability"; McLeod, "Women, peace and security," p. 21.

43 Asian Development Bank, Reforms in the Pacific, An Assessment of the Asian Development Bank's Assistance for the Reform Programs (Manila: ADB, 1999) p. 144. For accounts of this period see Van Trease, Melanesian Politics; Ambrose, A coup that failed and Morgan, Political Chronicles. 
quiescence. ${ }^{44}$ Collier makes a compelling argument for decoupling normative notions of "good governance" from the conflict discourse: income disparity, the lack of democratic rights, and ethnic and religious diversity have no discernible effect on the outbreak of violence. ${ }^{45}$ These, he suggests, are proxies for objective grievances. In his opinion, greed is the prime motivator, a point that highlights the need to undermine arbitrary assumptions which link homogeneity, stability and development.

In 1995, Vanuatu was accorded UN Least Developed Country status on account of its relatively low income, human resource weaknesses and high degree of economic vulnerability. Vanuatu is the third poorest country in the Pacific, with a per-capita GDP of US $\$ 1,276 .{ }^{46}$ Vanuatu, like the Solomon Islands and Papua New Guinea, ranks poorly on the UNDP Gender-Related Development Index ${ }^{47}$ Statistics are unavailable for the number of ni-Vanuatu beneath the poverty line, but Vanuatu is often rated poorly vis-à-vis other developing countries on the UNDP Poverty Index. ${ }^{48}$ Among 111 developing countries graded by the United Nations Conference on Trade and Development, Vanuatu was ranked the most vulnerable country. Lack of government co-ordination with private enterprises, entrenched political instability, declining customs and taxation revenues and poor global prices for Vanuatu's cash crops have all contributed to the weakening of the economy.

Vanuatu's economy is highly dualistic. Services and economic activity are largely concentrated in urban areas. (fuelled by proximity to the tourism sector and Vanuatu's offshore financial centre), with rural areas being characterized by a reliance upon subsistence agriculture, augmented by labour-intensive, low-yield cash crops and limited access to government services, especially health and education. This dualism presents both a source of dissatisfaction with the lack of basic services and contains several elements which insulate grassroots ni-Vanuatu from adverse shocks, primarily economic ones, but to a limited degree, also natural disasters, such as cyclones.

Food gardens are the main source of food in Vanuatu, allowing food production to maintain parity with population growth, even in the most heavily populated islands. Nonetheless, most people enjoy relative food

44 Frances Stewart, The Root Causes of Conflict: Some Conclusions, Working Paper no. 16. [Online, cited 3 April 2006]. Available from http://www.reliefweb.int/library/documents/queenelizawps16.pdf, p. 2.

45 Collier, "Economic causes of civil conflict," p. 7.

46 United Nations, Common Country Assessment: Vanuatu (Suva: Office of the United Nations Resident Coordinator, 2002), p. 14.

47 United Nations Development Program (UNDP), Pacific Human Development Report (Suva, Fiji: UNDP 1998), p. 16.

48 See Asian Development Bank (2000), Vanuatu Country Performance Indicators. [Online, cited 3 April 2006]. Available from http://www.adb.org/documents/CAPs/VAN/appendix.pdf, at p. 2. UNDP, Pacific Human Development Report, p. 18. 
security based on subsistence agriculture, access to safe water and sanitation. Donors have highlighted Vanuatu's narrow revenue base-which relies heavily on tourism, agriculture and narrow financial services-as an area for immediate reform and have become particularly concerned with reportedly growing wealth disparities. Because economic reform and economic development are linked closely to issues such as rural development and land reform, economic reforms and economic development themselves contain the seeds of potential future conflicts.

In Solomon Islands, unchecked logging resulted in land disputes, alienation, resource depletion and violence. In Vanuatu, conflicts associated with logging have involved all key stakeholders: the government, the landowners, and the logging companies. The majority of conflicts have occurred between landowners and logging companies and most have been low level. ${ }^{49}$ The worst case involved the burning of a bulldozer owned by a subsidiary of the Malaysian-owned company, Rimbunan Hijau, in northeastern Santo by landowners claiming the illegal exploitation of their forest reserves. Legislative reforms have been aimed at controlling and monitoring the performance of companies involved in logging, problems of policing the law notwithstanding. The impact of community logging projects and more sustainable practices is yet to be fully realized. Nonetheless, intensified logging may result in intensified conflict.

Grievances over economic disadvantage have certainly caused social unrest (rioting, looting) in Vanuatu. The 1998 Vanuatu National Provident Fund Riots focused attention on the social impact of poorly managed financial institutions and possibly corrupt practices. In 1997, the ombudsman tabled a 100-page report detailing gross mismanagement and corruption in the upper echelons of the Vanuatu National Provident Fund (VNPF), the retirement fund to which all employees in Vanuatu make mandatory contributions.

In 1993, the Ministry of Finance and the Vanuatu National Provident Fund established a housing loan scheme with VNPF moneys. The ombudsman's report stated that between 1994 and 1995 the Korman Government had directed the VNPF management to provide special conditions on these loans for government officials, ministers and others who were to be given them. After two years the scheme had expended several million vatu (vt), but benefited only 150 people. ${ }^{50}$ The report sparked a demonstration from disgruntled VNPF members. In late December, they began applying for loans similar to those offered to politicians. Frustrated by government inaction and their inability to access the loans that were

49 Ralph Regenvanu, Luca Tacconi and Steve Wyatt, "Changing Forestry Regimes in Vanuatu: Is Sustainable Management Possible?" Contemporary Pacific, vol. 9, no. 1 (1997), p. 82.

50 Vanuatu Weakly, $06 \mathrm{Jul} .1996$. 
available to the political affiliates of national leaders, members of the crowd rioted, causing an estimated vt 200 million damage. ${ }^{51} \mathrm{~A}$ number of business residences were targeted during the melee, most notably those belonging to local businessman, Dinh Van Than, chairman of the National United Party's People's Congress. Outnumbered and ill-prepared, the police were unable to disperse the protesters.

In light of recent financial scandals in Vanuatu, the potential for economic disaster is acute, with significant effects for all ni-Vanuatu. Recently enacted financial regulations and improvements in the operation of the Department of Finance might ameliorate these concerns. Clearly economic reforms and the tightening of regulations governing financial institutions have transparent effects, notably removing the triggers for incidents such as the 1998 riots. Yet socio-economic factors have contributed to growing disputes, particularly in urban areas. It is to the potential of these structures to lead to the outbreak of violence that we now turn.

\section{Social instability and violent conflict}

Throughout Melanesia, urbanization, unemployment, land tenure issues and ethnic tensions are posited as potential roots of violent conflict, all of which are indeed apparent in Vanuatu. In contemporary Vanuatu, rapid urbanization constitutes a potential source of conflict, distilling the tensions created by land claims, ethnic diversity and the growing young population. The most recent census showed that Vanuatu's towns were growing at almost twice the rate of rural areas. ${ }^{52}$ Escalating urbanization and the exponentially increasing disparity between job seekers and employment opportunities, concentrated in urban areas, is now seen as a major contributory factor to worsening crime rates (as in Papua New Guinea) and a potential source of instability.

Unchecked urbanization has forced "embattled" national administrations and donors alike to adopt decentralization and local empowerment as goals to reverse these trends. To date, Pacific governments have failed to balance urban development problems because of their inability to generate rural employment and because attainable rural opportunities are rarely as attractive as elusive urban ones. Urbanization has placed a strain on family and community networks in urban areas that are unable to absorb or support high numbers of under-skilled, unemployed island immigrants.

Additionally it has distilled land issues in proximate areas. Land is an issue of central importance to ni-Vanuatu. In common with most Melanesians, ni-Vanuatu ties to the land transcend simple property rights; the land contains

51 Trading Post, Port Vila, Vanuatu, 17 Jan. 1998, p. 6.

52 National Statistics Office, Vanuatu, The 1999 Vanuatu National Population, p. 39. 
historical, cosmological and genealogical significance. ${ }^{53}$ Although most settlements in urban Vanuatu were established initially with the consent of traditional landowners, tension has mounted because of the concentration of immigrants and the perceived abrogation of the rights of traditional owners. For example, in the Blacksands settlements on the outskirts of Port Vila, periodic flare-ups between the traditional Ifiran owners and Blacksands residents have occurred over land usage. Concerns that immigrants will divest the traditional owners of their holdings are significant and may escalate in the longer term. This issue remains prominent despite the comprehensive integration of Ifira into the cash exchange economy and the relative wealth of many of its inhabitants.

Land tenure systems in Vanuatu have been depicted as a significant disincentive to investment, an obstacle to optimal land use, representative of an ongoing source of local or "next-to-local" conflict and a strain on the legal system. ${ }^{54}$ Proposed government intervention to remedy this, especially through regulation, has been criticized as confrontational. A lands tribunal has been created and this might impact on land claims deliberations and provide the means to arbitrate these conflicts. However, changes in grassroots attitudes to land tenure will occur only slowly. Judging by the experience in Papua New Guinea, unilateral government intervention or attempts to mobilize land-even with apparently necessary economic reforms in mindmay provoke unified resistance or at least widespread discontent at the local, provincial and national levels.

In addition to land, Vanuatu's young people, particularly young men, are seen to pose a significant threat to the country's stability, especially in urban areas. ${ }^{55}$ In 2001, Prime Minister Edward Natapei commented that "urban areas cannot provide adequate employment opportunities for ... young people who may become frustrated and ultimately resort to anti-social behaviour as has occurred in some of our neighbours. ${ }^{" 56}$ Given that 60 per cent of Vanuatu's population is under 25, the comparative weight of numbers suggests that this will be a long-term policy concern. ${ }^{57}$ Every year about 4,000 new job seekers compete for about 500 new jobs created by a combination of foreign investment, limited local entrepreneurship and government initiatives. Young people decry the lack of opportunity available in urban

53 See for example Chris Ballard, "It's the land, stupid: the moral economy of resource ownership in Papua New Guinea," in Peter Larmour, ed., The Governance of Common Property in the Pacific Region (Canberra: National Centre for Development Studies, 1997), pp. 49-51.

54 See Asian Development Bank, Reforms in the Pacific, p. 173; Peter Larmour, ed., The Governance of Common Property in the Pacific Region, p. 1.

55 Volker Boge, "Conflict Potential and Violent Conflict in the South Pacific: Options for a Civil Peace Service," Working Paper no. 1/2001 (Hamburg: Research Unit of Wars, Armament and Development, University of Hamburg, 2001).

56 Port Vila Presse 18 Aug. 2001, p. 1.

57 National Statistics Office, Vanuatu, The 1999 Vanuatu National Population, pp. 17-18. 
areas, despite suggestions that young people are increasingly inclined to migrate to urban areas in search of work. ${ }^{58}$ There is a growing perception that expatriates dominate economic opportunities in urban areas. In the short term this is unlikely to foment civil unrest but will contribute to worsening crime rates.

Due to the high numbers of young men committing crimes, the legal justice system is overburdened. The preponderance of young people facing court reflects the systemic inability of national and provincial governments, and the private sector to provide opportunities for young people. Furthermore, young people are unable to access relevant information regarding a variety of key issues, including restorative justice and the law. Despite their ability to organize in creative and effective ways, demonstrated particularly in the Vanuatu Young People's Project and the Foundation for the Peoples of the South Pacific (FSP) Youth Drop-in Centre, young people feel disenfranchised by national leaders and under-serviced by state institutions. ${ }^{59}$

While the National Summit on Juvenile Justice in 2001 proposed that the empowerment of chiefs would assist in alleviating pressures on the formal justice system, young people have voiced cogent reservations about the ability of chiefs to deliver justice better and ensure peaceful social relations. ${ }^{60}$ Tension is evident between nostalgic notions of kastom (those practices believed to be traditional), the priorities of customary leaders and the priorities of young people, especially young women.

Like land and youth unemployment, ethnic tension has been highlighted as a potential source of instability in Vanuatu. In the "Security in Melanesia" report presented to the Forum Regional Security Committee (FRSC) in May 2001 (in the aftermath of ethnic fighting in Solomon Islands), it was suggested that because of Vanuatu's cultural diversity "there is a great potential for ethnic tension, especially in urban areas with large squatter settlements and numerous under educated, unemployed men. ${ }^{61}$ In 2004, this fear continued to underlie many discussions of state security and instability in Vanuatu ${ }^{62}$ However, both the Carnegie Commission ${ }^{63}$ and Collier ${ }^{64}$ suggest that diversity impedes serious conflict. Indeed, Collier claims that "diversity makes a society

58 Michael Morgan, "Disentangling kastom law and social justice," Development Bulletin, (Young People and Development), no. 56, October (2001), pp. 58-62.

59 See Michael Morgan, "Governing for the Future: Young People and Vanuatu's Governance Agenda," Workshop Report, 2001. [Online, cited 4 April 2006]. Available from http:// rspas.anu.edu.au/papers/melanesia/conference_papers/2001/Vanuatu01-Report.pdf.

60 Morgan, "Disentangling kastom."

61 Anere et al. "Security in Melanesia," p. 41.

62 See McLeod, Report on the National Security Worksop, Vanuatu.

63 Carnegie Commission, Preventing deadly conflict: Final noport. [Online, cited 4 April 2006 ]. Available from http://wwics.si.edu/subsites/ccpdc/pubs/rept97/toc.htm

64 Collier, "Economic causes of civil conflict." 
considerably safer" from civil war because it makes the mobilization of people on the basis of kinship, language or religion difficult. ${ }^{65}$

The corollary of this position is that the presence of one dominant ethnic group which "constitutes 45 to 90 percent of the population doubles the risk of conflict [civil war]. ${ }^{n 66}$ The lack of any such group in Port Vila or Luganville presumably insulates Vanuatu from an outbreak of serious violence akin to Collier's conception of civil war. In settlements around Port Vila, several different island communities reside in close proximity, or dispersed settlements. The major communities in Blacksands Settlement are from Whitesands in Tanna but many other island communities are represented in the population. ${ }^{67}$ Indeed, while Tannese immigrants constitute the single largest group of inter-island immigrants residing in or nearby Port Vila, the breakdown of in-migrants by province presents a much more complex picture; Malampa Province (comprising the islands of Malakula, Paama, Ambrym) provides most of Shefa Province's inter-island immigrants. ${ }^{68}$ The relative dispersal of island communities in urban areas lessens the chance of protracted ethnic violence by diluting the "them-us" dichotomy. Furthermore, the presence of several "ethnic" communities has served to ameliorate the ascendancy of one particular group over another, hence limiting opportunities for resource domination by a single group. Ethnic diversity has, however, contributed elsewhere to worsening crime rates in urban areas. Thus while it may not contribute to serious violent conflict, it could possibly contribute to the general escalation of crime, including violent crime, in Vanuatu.

The pressing issue in peri-urban settlements, however, is not ethnic diversity, but rather, poverty. Residents depict the settlements as ples blong pua man (the place of the poor man) ${ }^{69}$ Few services are available to Blacksands residents, for example, and unemployment appears to be common. Significantly, a large proportion of participants in the 1998 VNPF riots were residents of the Blacksands settlements. While the previously mentioned Forum Regional Security Committee report flagged ethnic diversity as a potential source of conflict, it gave little consideration to the key underlying social, political and economic forces that might exacerbate brewing conflicts and, ultimately, little consideration to what kinds of conflicts could be created by these social factors. ${ }^{70}$ Potential ethnic problems in Vanuatu would invariably emerge from economic bases, in terms of access to land, and less

65 Collier, "Economic causes of civil conflict," p. 11

66 Collier, "Economic causes of civil conflict," p. 7.

67 Jean Mitchell, "Violence as continuity: violence as rupture - narratives from an urban settlement in Vanuatu," in Sinclair Dinnen and Allison Ley, eds., Reflections on Violence in Melanesia (Leichhardt, NSW: Hawkins Press, 2000), p. 119.

68 National Statistics Office, Vanuatu, The 1999 Vanuatu National Population.

69 Jean Mitchell, Hanem Vois blong Yangfala long Vila Taon (Port Vila: Vanuatu Young People's Project, 1998), p. 192.

70 Anere et al., "Security in Melanesia." 
commonly control of employment opportunities. There has been low-level conflict in the Blacksands settlements between the Ifiran landowners and inter-island immigrants over uncontrolled population increases, based on the fear that Ifiran land claims will be diluted or extinguished by the weight of immigrants. Similarly, civil unrest in Luganville in December 1999 was sparked by personal rivalries between urban youths, but was fuelled by the perception that inter-island immigrants, rather than Santo locals, monopolized employment opportunities. While tension of this kind has sparked low-level conflict in urban areas, it has threatened neither provincial nor national governments directly, and has usually been contained quickly.

The potential for worsening law and order in Vanuatu, particularly in urban areas, is increased by the low emphasis placed on community policing. Until recently police engaged with communities only occasionally, with punitive raids appearing to be commonplace policing strategies in the aftermath of instances of civil unrest or to counter perceived criminal acts. Currently, cases are being pursued against the VMF and VPF for the use of unreasonable force during Operation Klinim North in Santo (which was mounted in response to deteriorating law and order in Luganville) in January 2000. As a result of the investigation into Operation Restore Public Hope, mounted in the aftermath of the VNPF Riots, the acting public prosecutor brought charges of intentional assault against eighteen VMF and police officers, two of senior rank. Instances of police brutality have engendered negative reactions in the community. Young, unemployed men in settlement areas appear to be particularly at risk. Testimony collected in the Blacksands settlements ${ }^{71}$ suggests that young people are reluctant to help police on account of their treatment in custody and particularly young men in Luganville, Santo, express the desire to rise in anger against the state on account of their treatment during Operation Klinim North. ${ }^{72}$

As elsewhere, poverty in Vanuatu has been highly feminized. Ni-Vanuatu women are less educated than men, hold few decision-making positions and suffer from high levels of domestic violence. ${ }^{79} \mathrm{Schmeidl}$ and Piza-Lopez argue that the more inclusive a society is, the less likely it is to resort to violence as a means of resolving conflict. ${ }^{74}$ In Vanuatu, women are far from achieving gender equality: of 52 seats in parliament only two are currently held by women; in 1999 , women held only 9 percent of the 346 top-level positions in decisionmaking bodies, and women are underrepresented in the law and justice sector, constituting a mere 5 percent of the Vanuatu Police Force (VPF) ${ }^{75}$

71 Mitchell, "Violence as continuity."

72 McLeod, "Women, peace and security," p. 22.

73 UNICEF, A situational analysis of children and women in Vanualu (Suva: UNICEF, 1998).

74 S. Schmeid] and E. P. Lopez, Gender and conflict early warning: A preliminary framework. [Online, cited 4 April 2006]. Available from http://www.international-alert.org/women/publications/ EWGEN.PDF.

75 Grace Molisa, Women and good governance (Port Vila: Blackstone Publishing, 2002), p. 5. 
While the direct causal link between gender inclusiveness and violent conflict is debateable, the prevalence (and tacit societal acceptance) of domestic violence as a means of resolving marital conflict suggests that, at some levels, violence is normalized. This raises concerns both in relation to the failure of the state to punish domestic violence offenders and the possibility that violence may become a more widely accepted mode of conflict resolution, hence contributing to a breakdown in law and order.

\section{Projections and Conclusions}

The examination of early warning indicators in the context of Vanuatu reveals the existence of conventional security, political, economic and social circumstances, which suggest the potential for armed conflict. Taken alone, however, early warning indicators do precisely that: they indicate potential, not inevitability. The history of conflicts in Vanuatu shows that while the potential for conflict has always been present, contemporary conflicts have remained small scale and rapidly contained. Unlike Papua New Guinea, there is no ongoing tradition of tribal warfare in Vanuatu and crime has not escalated to the point of creating a pervasive culture of violence, although the acceptability of domestic violence is of concern. ${ }^{76}$

While ni-Vanuatu attribute the containment and prevention of conflicts predominantly to the centrality of chiefs in the maintenance of social order, other factors are significant. As a starting point, ethnic diversity precludes the chance of the $\mathbf{8 , 0 0 0}$ or so teenage and adult males based in Port Vila rising against one another, or the government, for a unified cause. Moreover, should they have the will to do so, the supply and purchase of advanced weaponry would pose significant problems. Alternatively, the escalation of low-level violent crimes and intra-community conflicts poses a more immediate and likely problem in urban areas. Taken together, these factors suggest that while there is the potential for armed conflict in Vanuatu, it is neither imminent nor highly probable.

Throughout Vanuatu, indigenous strategies of peacemaking and conflict resolution have dissipated low-level conflicts effectively. Because the seeds of graver conflict may be contained within these grievances-bearing in mind the desirability of preventing armed conflict rather than dealing with its consequences-organic conflict resolution systems should be considered essential means of ensuring peace and stability. But a strengthened role for indigenous strategies of peacemaking and conflict resolution might affect other areas that are central to ongoing reform projects in Vanuatu. For example, while chiefs in Vanuatu have played a role in ameliorating local or next-to-local conflict, their priorities may differ markedly from young people

76 McLeod, "Women, peace and security," p.15. 
and women. For example, given that the empowerment of women, often considered crucial to effective conflict prevention strategies, is a United Nation's Millennium Development Goal, a strengthened role for chiefswho uphold male dominance-in conflict resolution may result in potential policy conflict.

In addition to the further legislative empowerment of the national chiefs, ni-Vanuatu who attended the 2004 Vanuatu National Security Workshop proposed a number of other initiatives aimed at the structural prevention of conflict and crime. ${ }^{77}$ Suggestions included both formal and informal sectorstrengthening initiatives, such as the legislative review of land law, continued institutional capacity building, increasing requirements for accountability, rural development, civic education and the strengthening of state and society relations. Significantly, such suggestions were largely in keeping with academic and practitioner approaches to the long-term prevention of conflict. ${ }^{78}$ However, the value of diversity, particularly in relation to women, is clearly subsumed by the desire to perpetuate the status quo (e.g., male and chiefly dominance) in the guise of kastom.

The Vanuatu context, in which conflict is certainly possible, yet not imminent, illuminates the difficulties of employing early warning systems to useful ends. Indeed, one may question the usefulness of early warning systems in the absence of similarly developed systems of early response. As highlighted in the abovementioned analysis, the Vanuatu context is riddled with factors that posses the potential to ignite conflict. However, in the absence of imminent conflict, operational prevention is unnecessary and the will to engage in structural prevention is significantly impeded by budgetary constraints, reluctance to engage with external priorities and the unstable policy environment. Such factors will clearly dictate the success or failure of future attempts to undertake the structural prevention of conflict in Vanuatu - a challenge to be met by both internal and external interests alike.

\section{Australian National University, November, 2006}

77 See McLeod, Report on the National Security Worksop, Vanuatu.

78 United Nations Secretary General, Prevention of Armed Conflict: Report of the Secretary General (New York: General Assembly, Security Council, 2001); Carnegie Commission, Preventing deadly conflict. 


\section{Informed Consent and Mining Projects: \\ A View from Papua New Guinea \\ Martha Macintyre}

Free, prior and informed consent is increasingly perceived as a means of ensuring that people's human rights are respected and their interests protected. This paper explores issues arising in the context of gaining informed consent about mining projects from people who are citizens of a developing nation. Assumptions about rights, processes of negotiation, scientific knowledge and environmental degradation are often alien to the local people involved. Drawing on anthropological research in Papua New Guinea, the complex interactions between understandings of scientists, environmentalists, corporation managers and indigenous people are examined. The pragmatic problems of ensuring that informed consent is gained and that the human rights of local people are equitably protected are explored and some tentative solutions offered.

\section{An Incomplete Arc: \\ Analyzing the Potential for Violent Conflict in the Republic of Vanuatu \\ Abby McLeod and Michael G. Morgan}

This paper seeks to analyze the potential for violent conflict in the Republic of Vanuatu, a small island state in the South West Pacific. It examines the likelihood of state level conflict and investigates local factors which might contribute to state destabilization. It seeks to redress the relative absence of Pacific conflicts from the international discourse on conflict and conflict prevention.

We argue that while Vanuatu possesses indicators of potential conflict, when violent conflicts have arisen in Vanuatu they have remained small scale and rapidly contained. In exploring this phenomenon, the paper charts factors such as formal and informal dispute resolution mechanisms, ethnic diversity, the availability of small arms and the incidence of violent crime. However, we note that strategies aimed at preventing the outbreak of violence may potentially create policy conflicts with other areas. In particular, we look at the effects of indigenous dispute resolution strategies on gender empowerment, one of the United Nation's Millennium Development Goals and a central premise of Australian Official Development Assistance to Vanuatu. 


\section{CONTRIBUTORS TO THIS Issue}

SAngbum Shin is an Assistant Professor in the Department of International Relations at Yonsei University, Wonju, Korea. His research Interests are on China's political economy, China's environmental policy and international environmental politics. Publications include "Economic Globalization and the Environment in China: A Comparative Case Study of Shenyang and Dalian," Joumal of Environment E Development, vol. 13, no.3, 2004, pp. 263-94, and "The Role of the Government in the Voluntary Environmental Scheme: The Case of ISO 14001 in China, "Issues \& Studies, vol. 41, no. 4, pp. 1-32. He may be contacted at <sshin@yonsei.ac.kr>.

Julie Gilson is senior lecturer in the Department of Political Science and International Studies at the University of Birmingham (UK). Her work includes Asia Meets Europe (Edward Elgar, 2002) and the co-authored Japan's International Relations (Routledge, 2005). She can be contacted at $<J . A . G I 1 S O N @ b h a m . a c . u k\rangle$

Martha Macintyre is Associate Professor and Reader in Anthropology at the University of Melbourne, where she teaches in the Centre for Health and Society, School of Population Health. She has worked as an independent consultant for the Australian government aid agency AusAID, for the Papua New Guinea Government and for mining companies. Her research in Papua New Guinea has concentrated on social and economic change in the context of large-scale mining projects; gender; law and justice and religion. Email <marthaam@unimelb.edu.au>.

Michael Morgan is a Visiting Fellow of the Pacific Centre at the Australian National University. He has worked as a consultant and academic in the areas of capacity building, conflict analysis, parliamentary strengthening and political party reform in Vanuatu, Papua New Guinea, Fiji, Solomon Islands, Philippines and Indonesia. He completed a doctoral dissertation on local conceptions of politics in Vanuatu from the Australian National University in 2003. He was co-editor and contributor to Political Parties in the Pacific Islands (Canberra: Pandanus Press, 2006). Among his other publications are "Cultures of dominance: institutional and cultural influences on parliamentary politics in Melanesia," SSGM Discussion Paper 05/2, 2005, "Political Fragmentation and the Policy Environment in Vanuatu, 1980," 2004, Vol. 19 (3), Pacific Economic Bulletin, 2004, and "Politik is poison: local conceptions of politics in Northern Vanuatu," The New Pacific Review, Vol. 2(1), December 2003.

Abny McLeod is a Postdoctoral Fellow at The Australian National University, Canberra. Her primary research interests are women and the law in Papua New Guinea, conflict and the cultural impediments to police reform. She may be contacted at <Abby.McLeod@anu.edu.au> 